University of Arkansas, Fayetteville

ScholarWorks@UARK

Education Reform Faculty and Graduate

Students Publications

Education Reform

7-1-2015

\title{
No Excuses Charter Schools: A Meta-Analysis of the Experimental Evidence on Student Achievement
}

\author{
Albert Cheng \\ University of Arkansas, Fayetteville, axc070@uark.edu \\ Collin Hitt \\ University of Arkansas, Fayetteville \\ Brian Kisida \\ University of Arkansas, Fayetteville \\ Jonathan N. Mills \\ Education Research Alliance for New Orleans
}

Follow this and additional works at: https://scholarworks.uark.edu/edrepub

Part of the Educational Assessment, Evaluation, and Research Commons, Educational Leadership Commons, and the Other Educational Administration and Supervision Commons

\section{Citation}

Cheng, A., Hitt, C., Kisida, B., \& Mills, J. N. (2015). No Excuses Charter Schools: A Meta-Analysis of the Experimental Evidence on Student Achievement. Education Reform Faculty and Graduate Students Publications. Retrieved from https://scholarworks.uark.edu/edrepub/48

This Article is brought to you for free and open access by the Education Reform at ScholarWorks@UARK. It has been accepted for inclusion in Education Reform Faculty and Graduate Students Publications by an authorized administrator of ScholarWorks@UARK. For more information, please contact scholar@uark.edu. 


\title{
No Excuses Charter Schools: A Meta-Analysis of the Experimental Evidence on Student Achievement
}

\author{
Albert Cheng \\ Collin Hitt* \\ Brian Kisida \\ University of Arkansas \\ Jonathan N. Mills \\ Education Research Alliance for New Orleans \\ EDRE Working Paper No. 2014-11 \\ Last Updated July 2015
}

\begin{abstract}
While charter schools differ widely in philosophy and pedagogical views, the United States's most famous urban charter schools typically use the No Excuses approach. Enrolling mainly poor and minority students, these schools feature high academic standards, strict disciplinary codes, extended instructional time, and targeted supports for low-performing students. The strenuous and regimented style is controversial amongst some scholars, but others contend that the No Excuses approach is needed to rapidly close the achievement gap. We conduct the first meta-analysis of the achievement impacts of No Excuses charter schools. Focusing on experimental studies, we find that No Excuses charter schools significantly improve math scores and reading scores. We estimate gains of 0.25 and 0.16 standard deviations on math and literacy achievement, respectively, as the effect of attending a No Excuses charter school for one year. Though the effect is large and meaningful, we offer some caveats to this finding and discuss policy implications for the United States as well as other countries. Keywords: charter schools, academic achievement, urban schools
\end{abstract}

*Corresponding Author; Email: cehitt@uark.edu 
No Excuses Charter Schools: A Meta-Analysis of the Experimental Evidence on Student Achievement

For a generation, the racial achievement gap has defined the debate over public education in the United States. According to the standardized tests administered by the US government, achievement in math and reading is consistently lower for Black and Hispanic students relative to White students. This problem is commonly known as the achievement gap (Hemphill, Vanneman, \& Rahman, 2011; Vanneman et al., 2009). Furthermore, the dropout rate for Black and Hispanic students is twice the national average (Heckman \& LaFontaine, 2007). These disparities underlie the present-day school reform movement. A signature change in education policy over the past fifteen years has been the advent of charter schools, hundreds of which have opened under the pretense of narrowing these achievement gaps in reading and math.

US charter schools are publicly-funded and given a wide degree of flexibility over instructional, curricular and staffing decisions. In exchange for this flexibility, charters are held accountable by some independent governing authority, such as a university, a local school district, or a state's government, to meet certain student-achievement benchmarks. These schools were first established in the United States in the state of Minnesota in 1990. Since then, charter schools have expanded throughout the country. Well over 2 million US students, representing about five percent of all public school students, are enrolled in charter schools today. True to the intent of improving educational opportunity most charter schools are intentionally located in higher-poverty areas. Data from the US Department of Education (2014) also show that charter schools serve a higher proportion of students in poverty or from racial minority backgrounds than traditional public schools. 
Charter schools, however, are not unique to the United States. Canada also has a system of charter schools. Analogous systems, called "free schools" or "independent schools," exist in other countries including Sweden, England, and New Zealand with the aim of improving educational opportunity. In each context, charter school policies are designed to allow for the opening of new schools that operate free from many (or most) of the regulations that govern traditional public schools. For example, a 1994 reform in Sweden allowed public funding to flow to private schools, and in turn a number of publicly-funded, privately managed "independent" schools were established in subsequent years. In England, "free schools" and "academy schools" are public schools that allowed to operate with a wide amount of operational autonomy, much like charter schools in the United States.

Another important feature of US charter schools is that they are schools of choice: Unlike traditional public schools where assignment to school is based upon place of residence, students may enroll in charter schools regardless of where they live. Free schools and independent schools in other countries are also often established as schools of choice. As schools of choice, charter schools often cater to niche demands and vary widely in philosophy and organizational structure. For instance, in the United States, a number of charter schools integrate facets of a particular ethnic culture, instructing children in its language, custom, and worldviews. These schools are called ethnocentric charter schools (Buchanan \& Fox, 2003). Others follow a particular pedagogical model such as the Waldorf or Montessori approach to education. Still others emphasize certain subject areas such as the performing arts or the STEM fields (science, technology engineering, and math).

In urban areas across the United States, far more so than in other locales, a philosophy called No Excuses has noticeably gained popularity among charter school operators. This 
philosophy has been heralded since 2003 by Thernstrom and Thernstrom in their book No Excuses: Closing the Achievement Gap in Learning. No Excuses schools focus intensely on raising the math and literacy scores of their students, who primarily come from low-income and racial minority backgrounds, in a deliberately regimented attempt to narrow the Black-White achievement gap that has defined debates over American education policy for over two decades. These types of charter schools in some American cities now make up a majority of the local charter school sector (Angrist, Pathak, \& Walters, 2013).

Studies of No Excuses charter schools are unique to the United States, as we have found, but the concerns about equity and academic achievement that No Excuses schools purport to address are familiar in other countries. Studies of No Excuses schools are currently limited to the United States for a number of reasons we discuss in the following sections. For one, the No Excuses model was developed first in the United States. Also, early in the American charter school movement, student-level data became widely available to researchers, as part of a larger national movement to expand the use of standardized tests and other performance metrics. This provided widespread, early opportunities to research the No Excuses model. In time it is possible that research will emerge exploring similar schools outside the United States.

No Excuses charter schools are characterized by holding their students to high academic expectations. One reason for these expectations is so that students are prepared for college. Indeed, No Excuses charter schools embrace a college-going culture - that is, they intently socialize and instill the goal of attending college into their students, many of whom would be the first in their families to do so. No excuses charter schools also feature strict behavior codes, extended instructional time, and targeted instruction (e.g., tutoring) for low-performing students. This approach to schooling has in some ways been prevalent in urban parochial schools for 
decades and was adopted in many early charter schools. Examples of those charter schools, including more recent networks adopting the same model, include the Knowledge is Power Program (KIPP), YES Prep, Uncommon Schools, Achievement First, and Aspire charter schools.

At the same time, however, critics charge that No Excuses charter schools are paternalistic and punitive, an approach frowned upon by some child psychologists (Goodman, 2013; Lack, 2009; Whitman, 2008). Others have questioned whether their pedagogical approach improves student learning. Horn and Wilburn (2013) describe No Excuses charter schools as providing "a regimented, zero tolerance model that contributes to...children who follow orders well but who think poorly" (p. 223). Clearly, No Excuses charter schools are the subject of much controversy and debate within education policy. The salience of the topic is evidenced by the growing research on the performance of these schools. In this article, we conduct a thorough review of this research and use meta-analytic techniques to estimate effects of No Excuses charter schools on student achievement in math and reading.

In particular, we focus only on studies that use experimental methods so that we can identify causal impacts of charter schools on student outcomes. Over the past five years, a sizeable number of experimental evaluations have been conducted of charter schools, and a subset of these experimental evaluations has focused on No Excuses schools. Experimental studies that investigate the achievement outcomes of charter school students take advantage of enrollment lotteries that charter schools must use when there are more students who apply to the school than there are available seats. By law, any charter school, including No Excuses schools, must hold admission lotteries to determine enrollment when it is oversubscribed. Because all students who apply to these oversubscribed charter schools are subsequently admitted by random chance, any differences in academic outcomes between students who receive admission and 
students who do not can be attributed to attending the charter school as opposed to other factors such as family background. Put differently, studies that use experimental research methods are free of selection bias because they only compare charter and non-charter students who were entered into enrollment lotteries. ${ }^{1}$ By only examining studies employing experimental methods in our review, we use the best evidence to make inferences about the causal impacts of No Excuses charter schools.

The primary strength of meta-analysis is that it combines studies with high internal validity into a larger analysis which improves external validity. Since existing studies typically focus on specific No Excuses schools that are located in a single city or belong to single charterschool network, the findings of any individual study cannot be generalized broadly. We use meta-analytic methods to overcome this limitation. We must, however, offer a caveat in our use of lottery-based studies. Random assignment studies cannot be performed at schools without lotteries. In the case of charter schools, it is possible that schools without waiting lists or wellmaintained lottery records may produce systematically different achievement results. Thus, the achievement impacts of charter schools with lotteries may not be representative of charter schools more generally.

For a broader view, one must consider the nonexperimental studies of charter schools. Research of US charter schools generally indicates that charter-school students perform at least

\footnotetext{
${ }^{1}$ One could also ask how (a) students who enter a lottery to attend a charter school compare with (b) students who do not enter a lottery and hence remain in traditional public schools. There may be concerns of selection bias as unobservable differences (e.g., motivation) would explain why one group enters a lottery while the other does not. As a result, it is impossible for research to make comparisons of these two groups of students that are free of selection bias. No research can make generalizations about students who do not enter a lottery and remain in traditional public schools based on comparisons to students who enter a lottery to enroll in a charter school. This issue, however, is not relevant for our review. Again, for our review, we gather research that analyzes students who opt into a lottery. Such research only compares students who win a lottery and those who lose a lottery, and because the lottery results are due to random chance, there is no selection bias issue when making such a comparison. Notably, this is the policy-relevant question. Policies are assessed based upon those who desire to participate in the intervention not on those who refuse it.
} 
as well as their student counterparts in traditional public schools on standardized achievement tests (CREDO, 2013; Zimmer et al., 2009). However, there is much heterogeneity in the results. Charter schools tend to be more effective in urban locales and in the elementary grades. Charter schools also improve over time, so older charter schools are more effective, and charter schools appear more effective at raising mathematics achievement than at raising reading achievement (Betts \& Tang, 2011). Charter school quality also varies across US states (Bifulco \& Ladd, 2006; Chingos \& West, 2015; Sass, 2006). In our discussion section, we revisit this issue and consider how other types of charter school studies bear upon our results.

Our focus upon No Excuses schools does create a geographic limitation of the studies we analyze. We found no experimental studies of such types of charter schools (or analogous free schools or independent schools) outside of the United States. Much of the existing literature outside of the United States focuses on the systemic effect that charter-like schools have on students both at charter schools and traditional public schools (e.g. Böhlmark and Lindahl, 2015; Ladd and Fiske, 2003). These studies are generally informative but do not provide information about any unique type of charter school, including No Excuses charter schools. Because of the current limits of the literature, our review focuses on studies within the United States. That said, we believe the lessons of No Excuses charter schools can be informative in other countries that struggle with the familiar problem of achievement gaps between at-risk students and their peers.

To conduct this study, we first collected every known random-assignment evaluation of charter schools and conduct a meta-analysis of the random-assignment literature of all charter schools. We then conduct a meta-analysis of the subset of random-assignment studies that focus on No Excuses charter schools. We estimate grand effect sizes for both intent-to-treat (ITT) and treatment-on-treated (TOT) estimates. We focus on two popular estimators in the program 
evaluation literature: the intent-to-treat (ITT) and treatment-on-treated (TOT) estimators (see, for example, U.S. Department of Health and Human Services, 2010; Wolf et al., 2010). The ITT estimator focuses exclusively on the oversubscription lottery result, effectively estimating how receiving admission to a charter school impacts student achievement. By focusing only on the lottery outcome, rather than the choice of a student to enroll in a charter school, the ITT estimator provides an unbiased estimate of the program's effectiveness that is highly relevant to policymakers, who cannot force families to comply with the lottery outcome. ${ }^{2}$ In contrast, the treatment-on-treated (TOT) estimator attempts to estimate the impact of actually enrolling in a charter school by making a few assumptions about charter school uptake (Wolf et al., 2010). TOT estimators often use the oversubscription lottery result in an Instrumental Variables framework to predict the likelihood that one enrolls in a charter school. We separately estimate grand effect sizes for both the effect of winning a charter school oversubscription lottery (ITT) an the effect of enrolling in a charter school (TOT) because both estimators provide valuable insight into how charter schools affect student achievement.

This is the first study to develop generalizable conclusions about No Excuses charter schools based upon gold-standard research. The remainder of this paper proceeds as follows. The subsequent section describes our review of the literature and our criteria for including studies in the meta-analysis. Next, we describe our analytic methods, followed by a presentation of our findings. We then conclude with a discussion of our findings.

\section{Search Process and Screening Methodology}

\footnotetext{
${ }^{2}$ Intent-to-treat (ITT) analysis simply compares the average outcomes of students randomly assigned to the treatment and control groups. In doing so, the estimator does not attempt to account for how or if lottery scholarships were actually used. For example, lottery winners who declined to enroll in charter schools are still included in the treatment group in ITT analysis. In doing so, the ITT analysis makes full use of the random nature of the scholarship assignment process, and therefore provides unbiased estimates of the impact of receiving the opportunity to enroll in a charter school.
} 


\section{Overview}

The aim of our meta-analysis is to answer the following two research questions:

1. Do No Excuses charter schools raise student achievement in math and English language arts (ELA)?

2. Do student achievement gains differ between No Excuses charter schools and other charter schools?

We conducted a thorough search process with strict inclusion criteria to identify the research that is relevant for addressing these questions. The search process consisted of four steps: (a) a database search for titles, (b) a review of abstracts, (c) an initial full reading of the articles, and (d) an in-depth reading of the articles. At each step, we identified articles that do not satisfy our inclusion criteria and excluded them from our analysis. Our search procedure and selection process are depicted in Figure 1. We discuss each of the steps below. To ultimately be included in the review, we required the studies to satisfy seven conditions:

1. The study was conducted and published after 1990, the year when the first US charter school was established. There were no studies of charter schools prior to 1990.

2. The study examines schools in the United States.

3. The results include achievement outcomes in English language arts or math.

4. The study utilizes experimental methods.

5. The study must report non-random attrition in either the treatment or control groups.

6. The study must report or control for baseline equivalence between treatment and control groups.

7. Any study without the necessary statistics to derive point and interval estimates of an effect size (e.g. standard errors, sample standard deviations) would be excluded. 


\section{«Figure 1 Approximately Here»}

\section{Database search}

After establishing these inclusion criteria, we identified titles that would be pertinent to our analysis. We searched numerous databases of peer-reviewed journal articles, dissertations, research reports that are self-published by research or academic institutions, and working papers. In particular, we used Ebsco, ProQuest, Jstor, Google Scholar, and the database of working papers from the National Bureau of Economic Research (NBER) to identify these titles. We used two combinations of search terms, namely, (a) charter school and random assignment and (b) charter school and lottery. ${ }^{3}$ We perused the titles that emerged from the search results, immediately excluding titles that were irrelevant to this review. Upon selecting a title for inclusion, we perused its bibliography and the curriculum vitae of its authors for further titles that meet our search and inclusion criteria.

\section{Abstract Review}

After excluding titles that were irrelevant for our research question, we reviewed the abstracts of the remaining studies. Based upon the additional information included in the abstract, we further excluded some studies which we determined to not meet our inclusion criteria and marked the remaining studies for an initial full reading.

\section{Initial Full Readings}

The goal of giving the remaining articles an initial full reading was to decide which studies warranted an in-depth reading and coding of their details. Like the abstract reviews, the

\footnotetext{
${ }^{3}$ Although we restricted our search to studies that use experimental design, we did not restrict our search to No Excuses charter schools. We did this for two reasons. The first reason deals directly with one of our research questions: We must include studies of all charter schools because one of our research aims is to determine whether there is a difference between No Excuses charter schools and other charter schools that are also over-subscribed. Second, we conducted a broader search so that we would not unnecessarily omit titles that would not have appeared in a narrower search. For example, it is possible that a study does not refer to a charter school as No Excuses, but after further inspection it may be identified as such. By using broad search terms we produced a larger set of titles and reduced the possibility of erroneously omitting a title relevant to answering our research questions.
} 
initial full readings revealed new information about the studies, and those that did not meet inclusion criteria were excluded. We proceeded to give the articles that met the inclusion criteria an in-depth reading.

\section{In-depth Readings.}

Two readers then read and coded each article that was selected for in-depth review. The following information for each study was collected:

- the study citation,

- whether the study investigated No Excuses charter schools,

- the location of the charter school,

- the years of the study period,

- information about the study participants (e.g. size of treatment and control groups, grade range),

- school characteristics (e.g. grade range, school size, name of school and/or charter network it belongs to),

- the degree of baseline equivalence between the treatment and control groups,

- the amount and details of crossover between treatment and control groups,

- the amount and details of study attrition,

- English language arts achievement results, and

- math achievement results.

We are confident that we identified all available experimental studies of charter schools and also identified the subset of these studies that focus on No Excuses charter schools. In several instances, the study's authors explicitly refer to schools in their sample as No Excuses 
schools and describe the defining characteristics of these schools. Recall that the essential characteristics of No Excuses schools are:

- a culture of college-going and high expectations,

- strong disciplinary and dress codes,

- a longer school day and/or school year, and

- targeted instruction for students who fall behind their peers (Angrist, Pathak, \& Walters, 2013; Carter 2000; Dobbie \& Fryer, 2013; Fryer, 2011; Goodman, 2013; Thernstrom \& Thernstrom, 2003; Whitman, 2008).

Although some studies in our review do not explicitly mention the term No Excuses, we always considered the description of the schools included in the study. We also gathered additional information about these schools using the internet. Based on information provided by the study and our additional internet investigations, we were able to judge whether or not the schools in each study satisfied the criteria of a No Excuses school per our working definition of the term. That is to say, a school had to clearly meet all four defining features of a No Excuses charter school to be considered as such.

\section{Search and Screening Results}

In all, we identified over 5,000 titles through the database search. However, the search yielded many irrelevant titles. Almost 300 titles were retained for abstract review. ${ }^{4}$ After reviewing the abstracts, we determined 68 titles merited a full reading. A full reading informed us of additional studies that did not meet the inclusion criteria. For example, our focus on

\footnotetext{
${ }^{4}$ Our title search frequently used some information from study abstracts. Most of the titles in our database search were found via Google Scholar. That database, beyond providing the title and other publication details, provides a three- to four-line preview of the study abstract. Occasionally, we were able to use the preview information on Google School to eliminate irrelevant studies during the title search. Though some abstract information was used during a Google Scholar searches, studies were not logged as being included in the abstract review unless the researcher opened the full article entry.
} 
experimental studies led us to screen out studies of charter schools that use observational designs (e.g. Gutierrez, 2012; Witte et al., 2009; Wolfram, 2008; Woodworth, David, Guha, Wang, \& Lopez-Torkos, 2008). Each of these studies provides at least partial performance estimates for No Excuses charter schools. However, we do not include them in our analysis for the reasons stated earlier: The lack of random assignment enrollment data begs questions about student selection bias. Later in our conclusions, we discuss how the exclusion of these studies may affect the interpretation of the results and, ultimately, the assessment of the effectiveness of No Excuses charter schools.

A full reading of other studies revealed that they were earlier versions of another study. . For instance, "Who Benefits from KIPP” by Angrist, Dynarski, Kane, Pathak, and Walters (2010b) is a working paper version of "Inputs and Impacts in Charter Schools: KIPP Lynn," which was published in The American Economic Review by the same authors (Angrist, Dynarski, Kane, Pathak, \& Walters, 2010a). In these cases, we chose the most recent version of the study. Of the articles that received a full reading, 17 merited an in-depth review. Of these 17 articles, seven were excluded in our meta-analysis. Three were excluded because they did not meet some of our inclusion criteria. First, McClure, Strick, Jacob-Almeida, and Reicher (2005) used an experimental design to evaluate achievement gains of The Preuss School, a charter school located on the campus of the University of California at San Diego. Yet upon a careful reading of the article, we found no tests for baseline equivalence among lottery winners and losers. Nor did the authors provide enough statistical information in their results for us to calculate an effect size. We excluded this study for those two reasons. ${ }^{5}$ Second, we excluded

\footnotetext{
${ }^{5}$ McClure et al. (2005) found null to positive effects in achievement for students who attended Preuss, though it is unclear to what extent the authors controlled for baseline characteristics of students. Also, it is unclear whether Preuss could be considered a No Excuses charter school at the time of the study. Given these two facts, together with its relatively small sample size when compared to the other studies included in our meta-analysis, excluding
} 
Grigg and Borman's (2014) evaluation of two charter schools in Denver, Colorado because of evidence of differential attrition rates between treatment and control group students. Third, we excluded Hoxby and Rockoff's (2004) experimental study of Chicago charter schools, as it did not contain the necessary statistical information to be included in our meta-analysis.

The remaining four of the seven excluded articles met our inclusion criteria but were all studies of charter schools in Boston, MA or Lynn, MA (Abdulkadiroğlu, Angrist, Dynarski, Kane, \& Pathak, 2011; Angrist, Cohodes, Dynarski, Pathak, \& Walters, 2013; Angrist et al., 2010a; Cohodes, Setren, Walters, Angrist, \& Pathak, 2013). As such, much of the study samples overlapped across these articles. In fact, the study samples were all subsets of the study sample in Angrist, Pathak, and Walters's $(2011,2013)$ analyses of all charter schools throughout Massachusetts. For this reason, we use the estimates in Angrist, Pathak, and Walters (2011, 2013) for our meta-analysis and exclude the four studies of Boston, MA and Lynn, MA to avoid over-counting the effects of some charter schools. Though Angrist et al. (2011) is a working paper version of Angrist, Pathak, and Walters (2013), we include both in our meta-analysis because the latter possesses more recent TOT estimates and is missing ITT estimates, while the former reports ITT estimates but also has less recent TOT estimates.

At the conclusion of our screening process, we possessed ten articles that used experimental methods to analyze the effects that charter schools have on student achievement. Four of these ten articles did not evaluate No Excuses charter schools, while four of these studies solely evaluated No Excuses charter schools. The remaining two articles included an estimate for all oversubscribed charter schools and a separate estimate for No Excuses charter schools. 
When collecting estimates from an in-depth review of the articles, we established the following decision rules:

- If a study provided separate results for different years of exposure, we counted only the analysis that incorporated the longest duration of treatment. ${ }^{6}$

- If a study only presented results separately across grades (e.g. middle school/high school), we counted each separate analysis as a standalone estimate. ${ }^{7}$

- If a study pooled results across grades (e.g. middle school/high school), we used pooled results, even if breakdowns were given.

In total, we have 18 estimates of the effectiveness of oversubscribed charter schools, some of which use both ITT and TOT methods while others only utilize one of those methods. Nine of eighteen are estimates of the effectiveness of No Excuses charter schools.

Studies that do not focus on No Excuses charter schools cover a diverse array of charter schools over a wide geographic region. For example, Gleason, Clark, Tutle, and Dwoyer (2010) examine a nationwide sample of charter middle schools. While there certainly are No Excuses charter schools in the sample used by Gleason et al. (2010), there are other types of charter schools as well. The authors do not report subgroup reports for No Excuses charter middle schools. Such studies have been included in our overall analysis of charter school performance, but clearly could not be included in our analysis of No Excuses charter school performance.

The nine estimates of No Excuses charter schools also come from a variety of contexts. Some studies focus on schools operating within the same network. For example, Tuttle et al.

\footnotetext{
${ }^{6}$ This rule applied to two studies: Gleason et al. (2010) and Tuttle et al. (2013). For the purposes of the metaanalysis in the next section, this distinction is noteworthy but largely irrelevant, as these studies only represent $7.8 \%$ of the total number of ITT estimates and $4.0 \%$ of the total number of TOT estimates. Moreover, the 2 year estimates are similar to the 1 year estimates.

${ }^{7}$ For example, Dobbie and Fryer (2011) provided separate estimates of students who entered the kindergarten and middle school lotteries of the Harlem Promise Academies. At no point did the authors pool these results. The results were reported separately by the authors, and are thus counted separately in our analysis.
} 
(2013) is an evaluation of KIPP, a national network of No Excuses charter schools. Others studies evaluate a single charter school (Curto \& Fryer, 2012) or charter schools throughout an entire state (Angrist, Pathak, Walters, 2013).

Table 1 lists and summarizes the results of all the articles and estimates that inform our meta-analysis. In the far right columns, we indicate whether an estimate is conducted using ITT, TOT, or both methods and provide a simple vote-tally of the results of these estimates provide. The studies are also categorized by whether they focus exclusively on No Excuses charter schools. For general studies of charter schools, of the nine reading achievement findings that we identify, six report positive reading effects, two find no statistically significant differences, and one reports a negative finding. Of the nine math achievement effects we identify, eight report positive math impacts and one finds no significant differences. When we consider the estimates for No Excuses charter schools, six find positive effects and three find no significant differences for reading achievement. For math achievement, seven of the nine analyses find positive impacts, while two find no significant differences.

<Table 1 Approximately Here>

Generally speaking, these estimates suggest that oversubscribed charter schools of various types have a positive effect on student achievement. The same is true for No Excuses charter schools. However, simply tallying the results of studies does not provide a true estimate of the average magnitude or significance of these effects. For that, we turn to the statistical meta-analysis presented in the next section.

\section{Meta-Analytic Methods}

For our primary analysis, we use random-effects meta-analysis, which estimates a general effect size across studies examining heterogeneous populations. We chose this method over a 
fixed-effects meta-analysis, which essentially assumes that each of the individual studies considered are examining the same population of subjects. ${ }^{8}$ While it seems plausible that No Excuses charter schools across the nation have similar samples of students, we agree with Betts and Tang (2011), who argue that this assumption likely fails with respect to charter schools, given the great observed heterogeneity of charter schools. Random-effects meta-analysis provides a more flexible approach to analyzing the results of multiple studies.

Our random-effects meta-analysis simply uses a weighted average of the individual study effect sizes to estimate the overall effect of oversubscribed No Excuses charter schools. Our estimate of the grand effect size for oversubscribed No Excuses charter schools is given by $G$ in Equation 1:

$$
G=\frac{\sum_{i} W_{i} \delta_{i}}{\sum_{i} W_{i}}
$$

where $\delta_{i}$ is the reported effect size for study $i$ and $W_{i}$ is a study specific weight. For our purposes, each individual study is weighted by the inverse of the sum of its within-study effect size variance and an estimate of the variance in effects between studies. That is,

$$
W_{i}=\frac{1}{\operatorname{var}\left\{\delta_{i}\right\}+T^{2}}
$$

where $\operatorname{var}\left\{\delta_{i}\right\}$ is simply the squared value of the individual effect size's standard error $\left(\operatorname{se}\left\{\delta_{i}\right\}^{2}\right)$ and $T^{2}$ is an estimate of the true between-study effect size variance. ${ }^{9}$ Given that the betweenstudy effect size estimate is constant across studies, we are effectively weighting each finding by the precision of the estimated effect, with studies with smaller effect size standard errors contributing relatively more weight to the grand effect.

\footnotetext{
${ }^{8}$ For more detailed information on the differences between fixed- and random-effects meta-analysis, see Borenstein, Hedges, Higgins, and Rothstein (2009).

${ }^{9}$ Our random-effects meta-analysis is performed using Stata's metan command (Harris et al. 2008), which estimated between-study error variance using the Q statistic procedure developed by DerSimonian and Laird (1986). While highly popular, the DerSimonian and Laird random-effects meta-analysis estimator is inefficient in metaanalyses based on few studies (Jackson, Bowden, \& Baker, 2009).
} 
An alternative approach would be to weight individual effect sizes by the sample size, with larger studies contributing relatively more information to the estimated effect than smaller studies. Technically, this would ignore the different levels of precision achieved by different studies, which vary in analytic methods and data quality, though in reality, this weighting method should not produce widely different results given the strong relationship between standard errors and sample size. We tested this assertion by duplicating our analysis below while weighting for sample size instead of inverse variance. The results from the two methods were not significantly different.

\section{Results}

\section{Overall Results for Charter Schools}

We begin with a meta-analysis estimating the overall effect of oversubscribed charter schools on student math and reading achievement. We present both the ITT and TOT estimates. The results of this analysis are presented in Table 2 . The results presented in columns 2 through 5 are mutually exclusive, representing studies that either provided only results disaggregated by school type or studies that did not disaggregate their findings. ${ }^{10}$ The reported grand effect sizes are positive and largely significant at the 0.05 confidence level across all studies. Our primary results are presented in column 1, which pools all of the effect estimates, independent of school level. Each of the estimated grand effect estimates is significant and positive, with slightly larger effect estimates for math than reading. This is consistent with the general findings from charter school studies (Betts \& Tang, 2011).

\section{<Table 2 Approximately Here>}

\footnotetext{
${ }^{10}$ We use the random-effects estimator developed by DerSimonian and Larid (1986) in our meta-analysis. This method has been shown to be inefficient when a small number of studies are included (Jackson, Bowden, \& Baker, 2009). The results presented in columns 2 through 5 in Tables 2 through 4 likely reflect this imprecision, given the small number of studies included in the analysis.
} 
There is one finding in Table 2 that requires some explanation. In general, one should expect TOT estimates to be larger in magnitude than ITT estimates. This is because ITT is simply determined by the result of the lottery, and therefore may be attenuated by treatmentcontrol group crossover. Thus, it is interesting to find one case in which the TOT estimate is smaller than the ITT estimate (math in column 5). The lower TOT estimate in column 5 simply results from the fact that the ITT and TOT estimates are derived from slightly different studies samples; one study included only ITT estimates and two other studies included only TOT estimates. One of the studies (Hastings, Neilson, \& Zimmerman, 2013) that provided only TOT estimates had a slightly negative impact.

This is, perhaps, made clearer in Figures 2 through 5. These figures present forest plots that include both the grand effect estimates reported in Table 2 as well as the individual effect estimates contributing to the overall estimates. The numbers in these figures correspond to the study effect size estimates and the horizontal bars represent their corresponding 95 percent confidence intervals. The results corroborate the positive grand effect size estimates, with the weight of significant effect sizes clearly favoring the relevant treatment group. In addition, a comparison of Figures 4 and 5 demonstrates why the math TOT estimated grand effect size is smaller than the math ITT estimate: Figure 5 includes more studies and one of those studies (Hastings et al., 2012) has a negative estimated effect. Thus, the findings presented in Table 2 and Figures 2 through 5 indicate that oversubscribed charter schools generally have a positive impact on student achievement in both math and ELA, regardless of test type and impact estimator used.

<Figure 2 Approximately Here>

<Figure 3 Approximately Here> 
<Figure 4 Approximately Here>

$<$ Figure 5 Approximately Here>

\section{Specific Results for No Excuses Charter Schools}

Next, we examine the studies examining oversubscribed No Excuses charter schools.

These results are presented in Table 3 and are thematically similar to those presented in Table 2:

Charter schools are found to have positive and largely significant impacts on student

achievement independent of both test type and chosen impact estimator. We find, however, that the estimated grand effects for No Excuses charter schools tend to be larger in magnitude compared to the general analysis of charter schools. The findings presented in Table 3 clearly indicate a positive impact of oversubscribed No Excuses charter schools on student math and ELA achievement.

<Table 3 Approximately Here>

Similar to Table 2, there is one case, in which the reported TOT estimate is lower than the corresponding ITT estimate. As before, the difference (in math column 5) is due to the inclusion of the negative TOT estimate reported in Hastings et al. (2012). The results presented in Figures 6 through 9 confirm this.

<Figure 6 Approximately Here>

<Figure 7 Approximately Here>

<Figure 8 Approximately Here>

<Figure 9 Approximately Here>

In Table 4, we investigate the sensitivity of our results by removing studies from our sample. In particular, the estimates in columns 2 through 7 are the estimated grand effect size that results after removing the study in the column heading. For example, column 7 presents the 
resulting estimated grand effect sizes after we remove the Tuttle et al. (2013) evaluation of KIPP charter schools from our meta-analysis. In general, the results presented in columns 2 through 7 do not indicate that our positive findings are driven by any particular outlier in our sample of No Excuses charter studies, as the estimated grand effect from the entire sample is well-within the 95 percent confidence intervals when each of the studies are removed.

\section{Discussion and Conclusion}

\section{Summary of Results}

The results presented in the previous section confirm the descriptive findings presented in the previous section: Both oversubscribed No Excuses charter schools and charter schools more generally appear to have positive effects on student math and ELA achievement. While our

findings for the overall sample of random assignment studies on charter schools largely confirm the findings of a 2011 meta-analysis by Betts and Tang on charter school effects, our study adds to the literature on charter school achievement impacts by focusing on No Excuses charter schools. The results highlight the relative success of No Excuses charter schools, as the estimated grand effect sizes for the sample of No Excuses charter schools are consistently higher than those estimated for the more general sample of random assignment charter school studies. Math achievement for students who attend No Excuses charter schools is 0.25 standard deviations higher than those who attend traditional public schools. Reading achievement for students who attend No Excuses charter schools is 0.15 standard deviations higher than those who attend traditional public schools. Analogous differences for students who attend other types of charter schools are 0.15 standard deviations for math achievement and 0.07 standard deviations for reading achievement. 
Consistent with other research, we also find some evidence of heterogeneity in charter school effects (Betts \& Tang, 2011). For instance, No Excuses charter schools are more effective in improving math than in improving reading achievement, a pattern that is borne out in the literature. Other research has also found that charter schools are more effective in urban areas than in nonurban arears. Our findings may partially explain this pattern. Specifically, No Excuses schools do better than other types of charter schools, and at the same time, are primarily located in urban areas. Finally, our results suggest that No Excuses schools are more effective in middle and high schools. This pattern appears to differ from the broad literature which indicates that charter schools are more effective at the elementary school level. However, it is important to note that the number of studies of No Excuses schools at the elementary level is very limited. Most No Excuses schools only serve students starting in the middle school grades, precluding any confident claims about their effectiveness at the elementary school level.

The claim that No Excuses charter schools are more effective than other types of charter schools holds insofar as the overall sample of charter schools serves as an appropriate comparison group to appraise the effectiveness of No Excuses charter schools. One way to ensure a proper comparison group is to compare No Excuses charter schools to a nationally representative sample of other types of charter schools. We point out that one of the studies in the overall sample of random assignment studies is national in scope. The Gleason et al. (2010) study evaluates 36 charter middle schools across 15 US states. As it turns out, that study documents negative effects in the range of 0.05 to 0.10 standard deviations in math and reading achievement for charter schools. Furthermore, CREDO's (2013) nonexperimental analysis of a majority of charter schools across 27 US states documents positive effects of 0.01 standard deviations in reading achievement and no differences in math achievement. These effects are 
clearly much lower than those produced by No Excuses charter schools. Moreover, most studies in our overall sample of charter schools evaluate schools that are largely located within the same state or even city as the No Excuses charter schools in our sample. That location is held constant in comparing No Excuses schools to other charter schools provides additional justification for using the other charter schools in our analysis as a comparison group to appraise the effectiveness of No Excuses charter schools. It appears, therefore, that No Excuses charter schools not only outperform other types of charter schools within the same jurisdictions but also far greatly outperform other types of charter schools throughout the US.

\section{Magnitude of the Effects of No Excuses Charter Schools}

We interpret the effects of No Excuses charter schools to be large and meaningful. The Black-White math achievement gap is often equated to one standard deviation on standardized test scores, while Black-White literacy achievement gap ranges from about 0.7 to 0.8 standard deviations (Hill et al., 2007). The No Excuses approach to schooling aims explicitly to close this gap. To reiterate, we find that attending a No Excuses charter school for approximately one year increases student achievement by 0.25 and 0.16 standard deviations in math and literacy, respectively, net of the typical annual growth that students experience. According to Hill et al.'s (2007) standards, attending a No Excuses charter schools for one year closes approximately $25 \%$ of the Black-White math achievement gap and approximately $20 \%$ of the Black-white literacy achievement gap. A straightforward extrapolation of these results suggests that attending a No Excuses charter school for four to five years could eliminate the achievement gap.

To provide another sense of the effect size of No Excuses charter schools, one can observe the magnitude of the additional gains in learning from attending a No Excuses charter school relative to the magnitude of typical learning gains that students experience annually. Hill 
et al. (2007) document that average learning gains in math for students in grades 5 through 12 the typical age of No Excuses charter school students - is 0.23 standard deviations per year. The same group of students gains about 0.21 standard deviations in reading per year. Thus, the additional gain of 0.25 standard deviations in math that No Excuses charter schools provide is over double the amount of annual learning that the average student experiences. Similarly, the additional gain of 0.16 standard deviations in reading that No Excuses charter schools provide is approximately three-quarters of the annual learning that the average student experiences. The magnitude of these additional learning gains relative to typical annual learning gains, together with the proportion of the Black-White achievement gap that is closed, suggests that the effect size of No Excuses charter schools on math and literacy is large and meaningful.

\section{Limitations and Future Research}

Yet there are some research limitations to mention. Most importantly, the understanding and assessment of No Excuses charter schools is largely shaped and limited by research methods studying these schools. Though informative, such research cannot provide a conclusive appraisal of No Excuses charter schools, not to mention all charter schools. In social science, there is almost always a tradeoff when choosing a research design. Studies that maximize internal validity often sacrifice external validity, and vice versa. The primary value of meta-analysis is that it allows researchers to combine several studies with high internal validity into a single analysis that has high external validity. Still, more research would be helpful.

Specifically, our meta-analysis draws upon studies that use a random-assignment research design, which were made possible only by the fact that charter schools with waiting lists must determine enrollment by lottery. Though this gold standard research provides the strongest available causal evidence, using this high research standard also narrows the scope of schools 
examined to those with waiting lists and well-kept lottery records. Such schools may be not representative of all No Excuses charter schools. For example, when comparing nonexperimental estimates of over- and under-subscribed charters schools in Boston, Abdulkadiroglu et al. (2009) find positive effects in both instances, but they find that oversubscribed charter schools tend to outperform charter schools with lower demand. Using a similar approach and looking at a national sample of KIPP middle schools, Tuttle et al. (2013) compare KIPP schools that employed lotteries with non-lottery KIPP schools. They find that the non-lottery schools perform slightly lower in math, but produce similar effects in reading.

Charter schools are either oversubscribed or not oversubscribed for a nonrandom reason. For instance, better schools might have longer waitlists because of higher parental demand, a proposition that would explain the findings in Abdulkadiroglu et al.'s and Tuttle et al.'s studies. Parental demand for oversubscribed charter schools, especially oversubscribed No Excuses charter schools, may be higher due to their reputation of high academic quality. Indeed, parents rely on social networks and the name branding of schools when selecting schools for their children (Author Cite, 2014; Schneider \& Buckley, 2007; Schneider et al., 1997; Trivitt \& Wolf, 2010). Many of these who parents seek high academic quality and are able to recognize that higher-performing oversubscribed charter schools offer that feature (Bast \& Walberg, 2004; Schneider \& Buckley, 2007; Schneider et al., 1997; Solmon, 2003). Thus, while we can be very confident about the effects generated in our meta-analysis of experimental studies of charter schools, we cannot confidently assume that these effects are generalizable to all charter schools or all No Excuses schools, even as we leverage the ability of meta-analysis to increase external validity. 
Likewise, the recent increase in the volume of random-assignment studies of charter schools has had wide geographic coverage. But the studies of No Excuses charter schools are primarily concentrated on schools in the eastern United States. We anticipate that forthcoming studies will provide greater geographic diversity.

Finally, the research we analyze focuses primarily on achievement effects of charter schools, even though there are many other important educational outcomes. Unfortunately, few studies have looked at other learning outcomes, such as student motivation, engagement, and other personality dispositions and character traits that have been shown to be important determinants of future wellbeing (Amlund et al., 2011; Heckman, Stixrud, \& Urzua, 2006; Levin, 2012; Borghans et al., 2006). There is little research into how charter schools impact these noncognitive skills, though some studies have looked beyond test scores. For example, Zimmer et al. (2009) find that charter school students are more likely to graduate high school and attend college, and Booker et al. (2014) find that students who attend charter schools have higher educational attainment and higher incomes in adulthood. For example, Dobbie and Fryer (2013) find that students in a No Excuses charter school have lower incidences of teen pregnancy and incarceration. Still, much remains to be seen and would be informative for the policy debates over charter schools. For now, there is strong evidence that No Excuses charter schools increase achievement among disadvantaged students in the United States, particularly in the core subjects of math and literacy.

Insofar as these gains translate into improvements in later-life welfare, No Excuses charter schools could serve as an important model to schools serving disadvantaged students, particularly in the US. Future research and experimentation is required to know with confidence whether the findings among No Excuses charter schools are generalizable to other countries. 
That said, the notable achievement impacts of No Excuses charter schools in the United States could be of interest to policymakers in other countries where education systems have struggled with socio-economic gaps in achievement-test scores. 


\section{References}

References marked with an asterisk indicate studies included in the meta-analysis.

AUTHOR CITE. (2014).

Abdulkadiroğlu, A., Angrist, J.D., Dynarski, S.M., Kane, T.J., \& Pathak, P.A. (2011).

Accountability and flexibility in public schools: Evidence from Boston's charters and pilots. The Quarterly Journal of Economics, 126(2), 699-748.

Abdulkadiroğlu, A., Angrist, J.D., Cohodes, S., Dynarski, S.M., Fullerton, J., Kane, T.J., \& Pathak, P. A. (2009). Informing the debate: Comparing Boston's charter, private, and traditional schools. Boston, MA: Boston Foundation.

Almlund, M., Duckworth, A. L., Heckman, J., \& Kautz, T. D. (2011). Personality Psychology and Economics (NBER Working Paper No. 16822). Cambridge, MA: National Bureau of Economic Research.

Angrist, J.D., Cohodes, S.R., Dynarski, S.M., Pathak, P.A., \& Walters, C.D. (2013). Charter schools and the road to college readiness: The effects on college preparation, attendance and choice. The Boston Foundation: Boston, MA.

Angrist, J.D., Dynarski, S.M., Kane, T.J., \& Pathak, P.A. (2010a). Inputs and impacts in charter schools: KIPP Lynn. American Economic Review, 10(2), 239-243.

Angrist, J.D., Dynarski, S.M., Kane, T.J., \& Pathak, P.A. (2010b). Who benefits from KIPP? National Bureau of Economic Research (NBER Working Paper No. 15740). Retrieved from the NBER website: http://www.nber.org/papers/w15740

*Angrist, J.D., Pathak, P.A., \& Walters, C.R. (2011). Explaining charter school effectiveness. National Bureau of Economic Research (NBER Working Paper No. 17332). Retrieved from the NBER website: http://www.nber.org/papers/w17332 
*Angrist, J.D., Pathak. P.A., \& Walters, C.R. (2013). Explaining charter school effectiveness. American Economic Journal: Applied Economics, 5(4), 1-27.

Bast, J. L., \& Walberg, H. J. (2004). Can parents choose the best schools for their children? Economics of Education Review, 23(4), 431-440.

Betts, J., \& Tang, Y. (2011). The effect of charter schools on student achievement: A metaanalysis of the literature. Retrieved from the Center for Reinventing Public Education website: http://www.crpe.org/sites/default/files/pub_NCSRP_BettsTang_Oct11_0.pdf

Bifulco, R., \& Ladd, H. F. (2006). The Impacts of Charter Schools on Student Achievement: Evidence from North Carolina. Education Finance and Policy, 1(1), 50-90.

Böhlmark, A., \& Lindahl, M. (2015). Independent Schools and Long-run Educational Outcomes: Evidence from Sweden's Large-scale Voucher Reform. Economica. Retrieved from http://onlinelibrary.wiley.com/doi/10.1111/ecca.12130/full

Booker, K., Sass, T.R., Gill, B., \& Zimmer, R. (2014). Charter high schools' effect on long-term attainment and earnings. Retrieved from the Mathematica Policy Research website: http://www.mathematica-mpr.com/publications/pdfs/education/charter_long-term_wp.pdf

Borghans, L., Angela L. Duckworth, Heckman, J., \& Weel, B. ter. (2008). The Economics and Pscyhology of Personality Traits. Journal of Human Resources, 43(4), 972-1059.

Borenstein, M., Hedges, L.V., Higgins, J.P.T., Rothstein, H.R. (2009). Introduction to metaanalysis. Chichester, West Sussex, United Kingdom: John Wiley and Sons, Ltd.

Buchanan, N. K. \& Fox, R. A. (2003, February 23). To learn and to belong: Case studies of emerging ethnocentric charter schools in Hawai'i. Education Policy Analysis Archives, $11(8), 1-23$. 
Carter, S.C. (2000). No Excuses: Lessons from 21 High-Performing, High-Poverty Schools. Washington DC: The Heritage Foundation.

Chingos, M., \& West, M. (2015). The Uneven Performance of Arizona's Charter Schools. Educational Evaluation and Policy Analysis, 37(1), 120-134.

Cohodes, S.R., Setren, E.M., Walters, C.R., Angrist, J.D., Pathak, P.A. (2013). Charter school demand and effectiveness: A Boston update. Boston, MA: Boston Foundation.

CREDO. (2013). National Charter Study 2013. Stanford, CA: Stanford University.

*Curto, V.E., \& Fryer, R.G. (2012). The potential of urban boarding schools for the poor:

Evidence from SEED. Retrieved from http://scholar.harvard.edu/files/fryer/files/seed23.pdf

DerSimonian, R., \& Laird, N. (1986). Meta-analysis in clinical trials. Controlled Clinical Trials, $7(3), 177-188$.

*Dobbie, W., \& Fryer, R.G. (2011). Are high-quality schools enough to increase achievement among the poor? Evidence from the Harlem Children's Zone. American Economic Journal: Applied Economics, 3(3), 158-187.

*Dobbie, W., \& Fryer, R.G. (2012). Getting beneath the veil of effective schools: Evidence from New York City (NBER Working Paper No. 17632). Retrieved from the NBER website http://www.nber.org/papers/w17632

Dobbie, W., \& Fryer, R.G. (2013). The medium-term impacts of high-achieving charter schools on non-test score outcomes. (NBER Working Paper No. 19581). Retrieved from the NBER website http://www.nber.org/papers/w19581 
Fryer, R. G. (2011). Injecting Successful Charter School Strategies into Traditional Public Schools: A Field Experiment in Houston (NBER Working Paper No. 17494). Cambridge, MA: National Bureau of Economic Research.

*Gill, B., Furgeson, J., Chiang, H.S., Teh, B., Haimson, J., \& Verbitsky-Savitz, N. (2013). Working Paper: Replicating experimental impact estimates with nonexperimental methods in the context of control crossover. Washington, DC: Mathematica Policy Research.

*Gleason, P., Clark, M., Tuttle, C. C., \& Dwoyer, E. (2010). The evaluation of charter school Impacts: Final report (NCEE 2010-4029). Washington, DC: National Center for Education Evaluation and Regional Assistance, Institute of Education Sciences, U.S. Department of Education.

Goodman, J. T. (2013). Charter Management Organizations and the Regulated Environment: Is It Worth the Price? Educational Researcher, 42(2), 89-96.

Grigg, J., \& Borman, G. D. (2014). Impacts and alternatives: Evidence from an elementary charter school evaluation. Journal of School Choice, 8(1), 69-93.

Gutierrez, H.M. (2012). Charter schools in greater Los Angeles: An evaluative comparison of charter schools vis-à-vis traditional public schools (Doctoral dissertation). Retrieved from UMI Dissertation Publishing (3549282).

Harris, R. J., Bradburn, M. J., Deeks, J. J., Harbord, R. M., Altman, D. G., \& Sterne, J. A. C. (2008). metan: fixed- and random-effects meta-analysis. The Stata Journal, 8(1), 3-28.

*Hastings, J.S., Neilson, C.A., \& Zimmerman, S.D. (2012). The effect of school choice on intrinsic motivation and academic outcomes (NBER Working Paper No. 18324). Retrieved from the NBER website: http://www.nber.org/papers/w18324 
Heckman, J.J., \& LaFontaine, P. A. (2010). The American high school graduation rate: Trends and levels. The Review of Economics and Statistics, 92(2), 244-262.

Heckman, J., Stixrud, J., \& Urzua, S. (2006). The effects of cognitive and noncognitive abilities on labor market outcomes and social behavior. Journal of Labor Economics, 24(3), 411482.

Hemphil, F.C., Vanneman, A., \& Rahman, T. (2011). Achievement gaps: How Hispanic and White students in public schools preform in mathematics and reading on the National Assessment of Educational Progress (NCES 2011-459). Retrieved from the U.S.

Department of Education website: http://nces.ed.gov/nationsreportcard/pdf/studies/2011459.pdf

Horn, J., \& Wilburn, D. (2013). The mismeasure of education. Charlotte, NC: Information Age Publishing.

Hoxby, C.M., \& Rockoff, J.E. (2004). The impact of charter schools on student achievement. Retrieved from http://www0.gsb.columbia.edu/faculty/jrockoff/hoxbyrockoffcharters.pdf

*Hoxby, C. M., \& Murarka, S. (2009). Charter schools in New York City: Who enrolls and how they affect their student's achievement (Working Paper No. 14852). Retrieved from the NBER website: http://www.nber.org/papers/w14852

Jackson, D., Bowden, J., \& Baker, R. (2010). How does the DerSimonian and Laird procedure for random effects meta-analysis compare with its more efficient but harder to compute counterparts? Journal of Statistical Planning and Inference, 140(4), 961-970.

Lack, B. (2009). No excuses: A critique of the Knowledge Is Power Program (KIPP) within charter schools in the USA. The Journal for Critical Education Policy Studies, 7(2), 127153. 
Ladd, H. F., \& Fiske, E. B. (2003). Does competition improve teaching and learning? Evidence from New Zealand. Educational Evaluation and Policy Analysis, 25(1), 97-112.

Levin, H. M. (2012). More than just test scores. Prospects, 42, 269-284.

McClure, L., Strick, B., Jacob-Almeida, R., \& Reicher, C. (2005). The Preuss School at USCD: School characteristics and students' achievement. La Jolla, CA: The Center for Research on Educational Equity, Assessment and Teaching Excellence.

Sass, T. R. (2006). Charter Schools and Student Achievement in Florida. Education Finance and Policy, 1(1), 91-122.

Schneider, Mark and Jack Buckley. 2002. "What Do Parents Want from Schools? Evidence from the Internet." Educational Evaluation and Policy Analysis. 24(2): 133-144.

Schneider, Mark, Paul Teske and Melissa Marschall. 2000. Choosing Schools: Consumer choice and the Quality of American Schools. Princeton: Princeton University Press.

Thernstrom, A., \& Thernstrom, S. (2003). No excuses: Closing the racial gap in learning. New York, NY: Simon and Schuster.

Trivitt Julie R. and Patrick J. Wolf. 2011. "School Choice and the Branding of Catholic Schools." Education Finance and Policy 6(2): 202-245.

*Tuttle, C.C., Gill, B., Gleason, P., Knechtel, V., Nichols-Barrer, I., \& Resch, A. (2013). KIPP Middle Schools: Impacts on Achievement and Other Outcomes, Final Report. Washington, DC: Mathematica Policy Research.

U.S. Department of Health and Human Services, Administration for Children and Families. (2010). Head Start impact study: Final report. Washington, DC.

Vanneman, A., Hamilton, L., Anderson, J.B., \& Rahman, T. (2009). Achievement gaps: How Black and white students in public schools perform in mathematics and reading on the 
National Assessment of Educational Progress (NCES 2009-455). Retrieved from the US Department of Education website:

http://nces.ed.gov/nationsreportcard/pdf/studies/2009455.pdf

Whitman, D. (2008). Sweating the small stuff: Inner-city schools and the new paternalism. Washington, DC: Thomas B. Fordham Institute.

Witte J.F., Wolf P.J., Carlson D., \& Dean A. (2012). Milwaukee independent charter schools study: Finale report on four-year achievement gains. Retrieved from the School Choice Demonstration Project website: http://www.uaedreform.org/downloads/2012/02/report31-milwaukee-independent-charter-schools-study-final-report-on-four-year-achievementgains.pdf

Wolfram, G. (2008). Effect of time spent in charter schools on student test scores: A Michigan case study. Journal of School Choice, 2(1), 20-46.

Woodworth, K.R., David, J.L., Guha, R., Wang, H., \& Lopez-Torkos, A. (2008). San Francisco Bay Area KIPP schools: A study of early implementation and achievement. Final report. Menlo Park, CA: SRI International.

Wolf, P.J., Cheng, A., Batdorff, M., Maloney, L., May, J., Speakman, S. (2014). The Productivity of Charter Schools. The School Choice Demonstration Project, Department of Education Reform, University of Arkansas: Fayetteville, AR.

Wolf, P., Gutmann, B., Puma, M., Kisida, B., Rizzo, L., Eissa, N., \& Carr, M. (2010). Evaluation of the DC Opportunity Scholarship Program: Final Report (NCEE No. 2010-4018). Washington, DC: U.S. Department of Education, Institute for Education Sciences, National Center for Education Evaluation and Regional Assistance. 
Zimmer, R., Gill, B., Booker, K., Lavertu, S., Sass, T. R., \& John F. Witte. (2009). Charter Schools in Eight States: Effects on Achievement, Attainment, Integration, and Competition. Santa Monica, CA: RAND Corporation. 
Table 1: Random Assignment Estimates of Charter School Achievement Effects

\begin{tabular}{|c|c|c|c|c|c|c|c|}
\hline \multirow{2}{*}{ Study } & \multirow{2}{*}{$\begin{array}{c}\text { No } \\
\text { Excuses? }\end{array}$} & \multirow{2}{*}{ Location } & \multirow{2}{*}{ Schools } & \multicolumn{2}{|c|}{ Type of Estimate } & \multicolumn{2}{|c|}{ Results } \\
\hline & & & & ITT & TOT & ELA & Math \\
\hline Angrist, Pathak, \& Walters (2011) & No & Massachusetts (MA) & 7 middle & $\mathrm{x}$ & & + & + \\
\hline Angrist, Pathak, \& Walters (2011) & No & MA & 2 high & $\mathrm{x}$ & & + & + \\
\hline Angrist, Pathak, \& Walters (2013) & No & MA & 8 middle & & $\mathrm{x}$ & + & + \\
\hline Angrist, Pathak, \& Walters (2013) & No & MA & 2 high & & $\mathrm{x}$ & + & + \\
\hline Dobbie \& Fryer (2012) & No & New York City & 19 elementary & $\mathrm{x}$ & $\mathrm{x}$ & + & + \\
\hline Dobbie \& Fryer (2012) & No & New York City & 10 middle & $\mathrm{x}$ & $\mathrm{x}$ & 0 & + \\
\hline Gill, et al. (2013) & No & Anonymous & $\begin{array}{l}12 \text { middle and } \\
\text { high }\end{array}$ & $\mathrm{x}$ & & 0 & + \\
\hline Gleason, Clark, Tuttle, \& Dwoyer (2010) & No & 15 states & 36 middle & $\mathrm{x}$ & $\mathrm{x}$ & - & 0 \\
\hline Hoxby \& Murarka (2009) & No & New York City & 42 schools & & $\mathrm{x}$ & + & + \\
\hline Angrist, Pathak, \& Walters (2011) & Yes & MA & 9 middle & $\mathrm{x}$ & & + & + \\
\hline Angrist, Pathak, \& Walters (2011) & Yes & MA & 4 high & $\mathrm{x}$ & & + & + \\
\hline Angrist, Pathak, \& Walters (2013) & Yes & MA & 9 middle & & $\mathrm{x}$ & + & + \\
\hline Angrist, Pathak, \& Walters (2013) & Yes & MA & 4 high & & $\mathrm{x}$ & + & + \\
\hline Curto \& Fryer (2012) & Yes & Washington, DC & 1 boarding school & $\mathrm{x}$ & $\mathrm{x}$ & + & + \\
\hline Dobbie \& Fryer (2011) & Yes & New York City & 1 elementary & $\mathrm{x}$ & $\mathrm{x}$ & 0 & 0 \\
\hline Dobbie \& Fryer (2011) & Yes & New York City & 1 middle & $\mathrm{x}$ & $\mathrm{x}$ & 0 & + \\
\hline Hastings, Neilson, \& Zimmerman (2012) & Yes & Anonymous & $\begin{array}{l}2 \text { elementary, } 2 \\
\text { middle, } 1 \text { high }\end{array}$ & & $\mathrm{x}$ & + & 0 \\
\hline Tuttle et al. (2013) & Yes & 5 states and DC & 10 middle & $\mathrm{x}$ & $\mathrm{x}$ & 0 & + \\
\hline
\end{tabular}

Note: + denotes positive and statistically significant result; - denotes negative and statistically significant result; 0 denotes not a statistically significant result. Angrist, Pathak, Walters (2011) and Angrist, Pathak, Walters (2013) provide separate estimates for No Excuses Charter schools and all oversubscribed charter schools. 
Table 2

Estimated Grand Effect Sizes for All Charter Studies

\begin{tabular}{|c|c|c|c|c|c|}
\hline & $\begin{array}{l}\text { All } \\
(1)\end{array}$ & \multicolumn{3}{|c|}{ School Level } & $\begin{array}{c}\text { Not Disaggregated } \\
\text { (5) }\end{array}$ \\
\hline Grand Effect Size & $0.04 *[0.01,0.08]$ & $0.06 *[0.02,0.1]$ & $0.03[-0.02,0.07]$ & $0.11 *[0.02,0.21]$ & $0.09[-0.11,0.28]$ \\
\hline p-value & 0.02 & 0.01 & 0.31 & 0.02 & 0.39 \\
\hline \multicolumn{6}{|l|}{ ELA, TOT } \\
\hline Grand Effect Size & $0.07 *[0.03,0.11]$ & $0.06^{*}[0.02,0.11]$ & $0.04[0,0.09]$ & $0.21 *[0.09,0.32]$ & $0.18[-0.02,0.37]$ \\
\hline p-value & 0.00 & 0.01 & 0.07 & 0.00 & 0.07 \\
\hline Studies & 11 & 2 & 5 & 1 & 3 \\
\hline $\mathrm{N}$ & 86,740 & 16,187 & 36,656 & 4,103 & 29,794 \\
\hline Studies & 10 & 2 & 5 & 1 & 2 \\
\hline $\mathrm{N}$ & 53,335 & 16,187 & 32,726 & 3,255 & 1,167 \\
\hline \multicolumn{6}{|l|}{ Math, TOT } \\
\hline Grand Effect Size & $0.15^{*}[0.09,0.2]$ & $0.12 *[0.07,0.16]$ & $0.16 *[0.07,0.26]$ & $0.27 *[0.13,0.41]$ & $0.09[-0.04,0.22]$ \\
\hline p-value & 0.00 & 0.00 & 0.00 & 0.00 & 0.15 \\
\hline Studies & 11 & 2 & 5 & 1 & 3 \\
\hline $\mathrm{N}$ & 86,943 & 16,187 & 36,914 & 4,050 & 29,792 \\
\hline
\end{tabular}


Table 3

Estimated Grand Effect Sizes for No Excuses Charter Schools

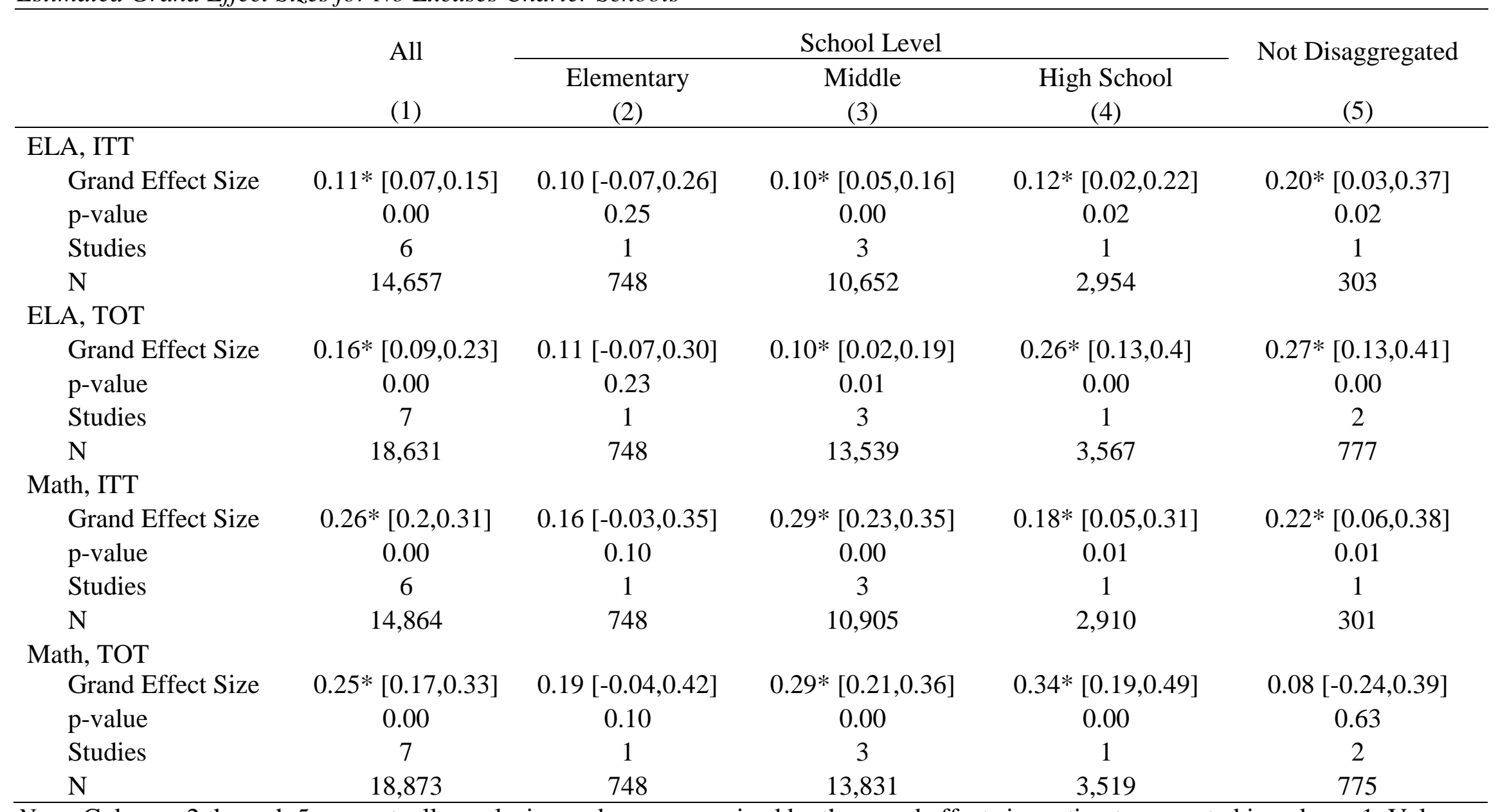

Note: Columns 2 through 5 are mutually exclusive and are summarized by the grand effect size estimates reported in column 1 . Values in brackets represent the lower and upper bounds of the associated 95 percent confidence interval. * indicates significance at the 0.05 level. 
Table 4

Impact on Estimated Grand Effect Sizes Due to Study Removal for No Excuses Charter Schools

\begin{tabular}{|c|c|c|c|c|c|c|c|}
\hline & \multirow[b]{2}{*}{$\begin{array}{c}\text { All Studies } \\
\text { (1) }\end{array}$} & \multicolumn{6}{|c|}{ Study Excluded } \\
\hline & & $\begin{array}{c}\text { Angrist, } \\
\text { Pathak, \& } \\
\text { Walters (2011) } \\
\text { (2) }\end{array}$ & $\begin{array}{c}\text { Angrist, } \\
\text { Pathak, \& } \\
\text { Walters (2013) } \\
\text { (3) }\end{array}$ & $\begin{array}{c}\text { Curto \& Fryer } \\
\text { (2012) } \\
(4)\end{array}$ & $\begin{array}{c}\text { Dobbie \& } \\
\text { Fryer (2011) } \\
(5)\end{array}$ & $\begin{array}{c}\text { Hastings et al. } \\
\text { (2013) } \\
(6)\end{array}$ & $\begin{array}{c}\text { Tuttle et al. } \\
(2013) \\
(7)\end{array}$ \\
\hline \multicolumn{8}{|l|}{ ELA, ITT } \\
\hline Grand Effect Size & $\begin{array}{c}0.11 * \\
{[0.07,0.15]}\end{array}$ & $\begin{array}{c}0.09 * \\
{[0.03,0.15]}\end{array}$ & N/A & $\begin{array}{c}0.11 * \\
{[0.06,0.15]}\end{array}$ & $\begin{array}{c}0.13^{*} \\
{[0.08,0.18]}\end{array}$ & N/A & $0.11 *[0.07,0.16]$ \\
\hline $\mathrm{p}$-value & 0.00 & 0.00 & N/A & 0.00 & 0.00 & N/A & 0.00 \\
\hline Studies & 6 & 4 & N/A & 5 & 4 & N/A & 5 \\
\hline $\mathrm{N}$ & 14,657 & 2,941 & $\mathrm{~N} / \mathrm{A}$ & 14,354 & 12,460 & N/A & 14,216 \\
\hline \multicolumn{8}{|l|}{ ELA, TOT } \\
\hline Grand Effect Size & $\begin{array}{c}0.16^{*} \\
{[0.09,0.23]}\end{array}$ & N/A & $\begin{array}{c}0.15^{*} \\
{[0.04,0.26]}\end{array}$ & $\begin{array}{c}0.16^{*} \\
{[0.08,0.24]}\end{array}$ & $\begin{array}{c}0.20 * \\
{[0.13,0.26]}\end{array}$ & $\begin{array}{c}0.14^{*} \\
{[0.07,0.21]}\end{array}$ & $0.16 *[0.08,0.24]$ \\
\hline $\mathrm{p}$-value & 0.00 & N/A & 0.01 & 0.00 & 0.00 & 0.00 & 0.00 \\
\hline Studies & 7 & N/A & 5 & 6 & 5 & 6 & 6 \\
\hline $\mathrm{N}$ & 18,631 & N/A & 3,415 & 18,328 & 16,434 & 18,157 & 18,190 \\
\hline \multicolumn{8}{|l|}{ Math, ITT } \\
\hline Grand Effect Size & $\begin{array}{c}0.26^{*} \\
{[0.2,0.31]}\end{array}$ & $\begin{array}{c}0.24^{*} \\
{[0.18,0.30]}\end{array}$ & N/A & $\begin{array}{c}0.26^{*} \\
{[0.19,0.32]}\end{array}$ & $\begin{array}{c}0.25^{*} \\
{[0.17,0.33]}\end{array}$ & N/A & $0.26 *[0.20,0.31]$ \\
\hline $\mathrm{p}$-value & 0.00 & 0.00 & N/A & 0.00 & 0.00 & N/A & 0.00 \\
\hline Studies & 6 & 4 & N/A & 5 & 4 & N/A & 6 \\
\hline $\mathrm{N}$ & 14,864 & 2,939 & N/A & 14,563 & 12,667 & N/A & 14,864 \\
\hline \multicolumn{8}{|l|}{ Math, TOT } \\
\hline Grand Effect Size & $\begin{array}{c}0.25^{*} \\
{[0.17,0.33]}\end{array}$ & N/A & $\begin{array}{c}0.20 * \\
{[0.08,0.31]}\end{array}$ & $\begin{array}{c}0.25^{*} \\
{[0.15,0.34]}\end{array}$ & $\begin{array}{c}0.25^{*} \\
{[0.13,0.37]}\end{array}$ & $\begin{array}{c}0.28 * \\
{[0.24,0.33]}\end{array}$ & $0.23 *[0.14,0.32]$ \\
\hline $\mathrm{p}$-value & 0.00 & N/A & 0.00 & 0.00 & 0.00 & 0.00 & 0.00 \\
\hline Studies & 7 & N/A & 5 & 6 & 5 & 6 & 6 \\
\hline $\mathrm{N}$ & 18,873 & N/A & 3,413 & 18,572 & 16,676 & 18,399 & 18,432 \\
\hline
\end{tabular}

Note: Values in brackets represent the lower and upper bounds of the associated 95 percent confidence interval. The ITT values in column (6) are not available ("N/A") because Hastings et al. (2012) only presents TOT estimates. * indicates significance at the 0.05 level. 
Figure 1. Search Procedure and Selection Process

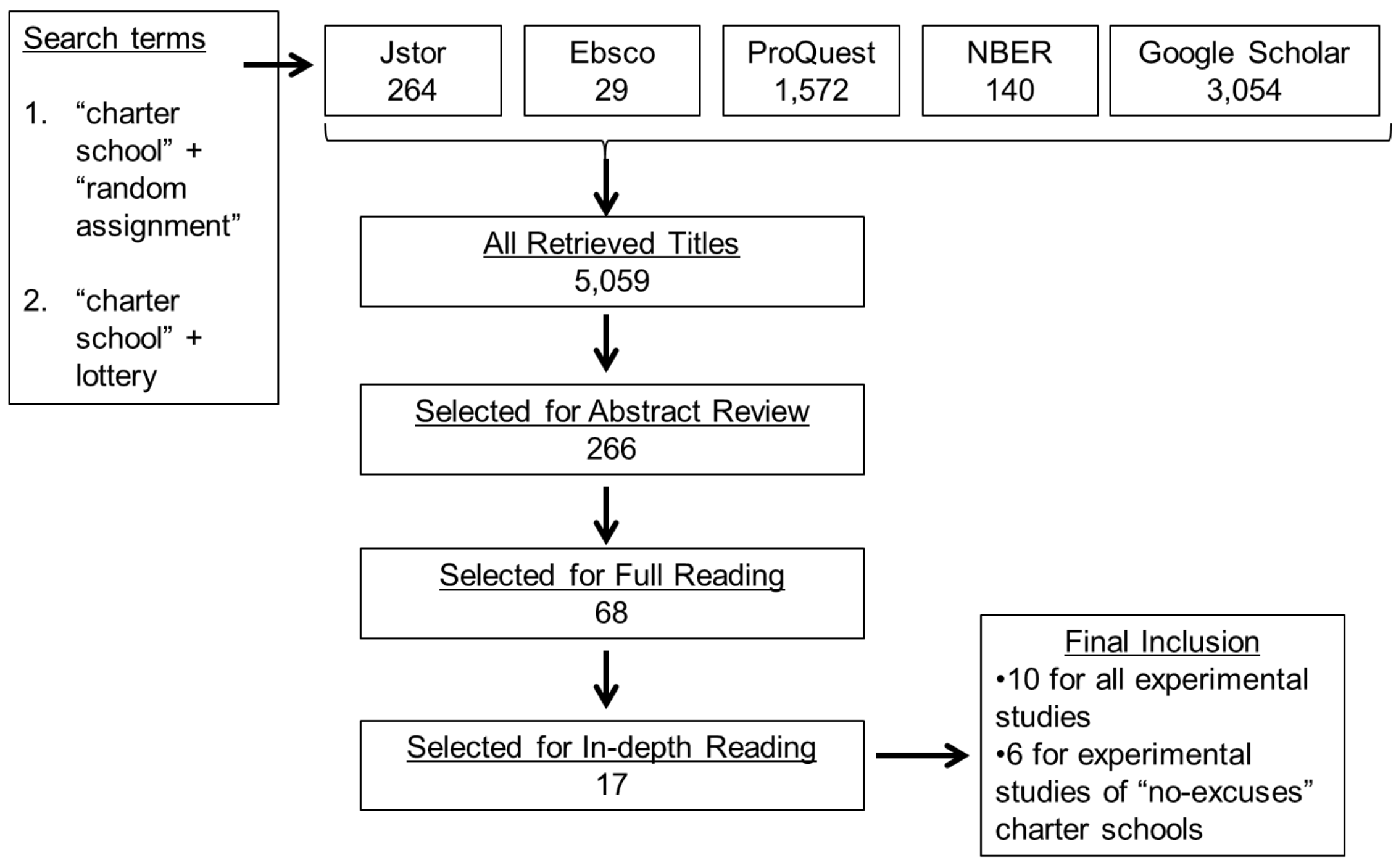


Figure 2. ITT estimates of individual-study and overall effect sizes for the impact all charter schools on ELA achievement.

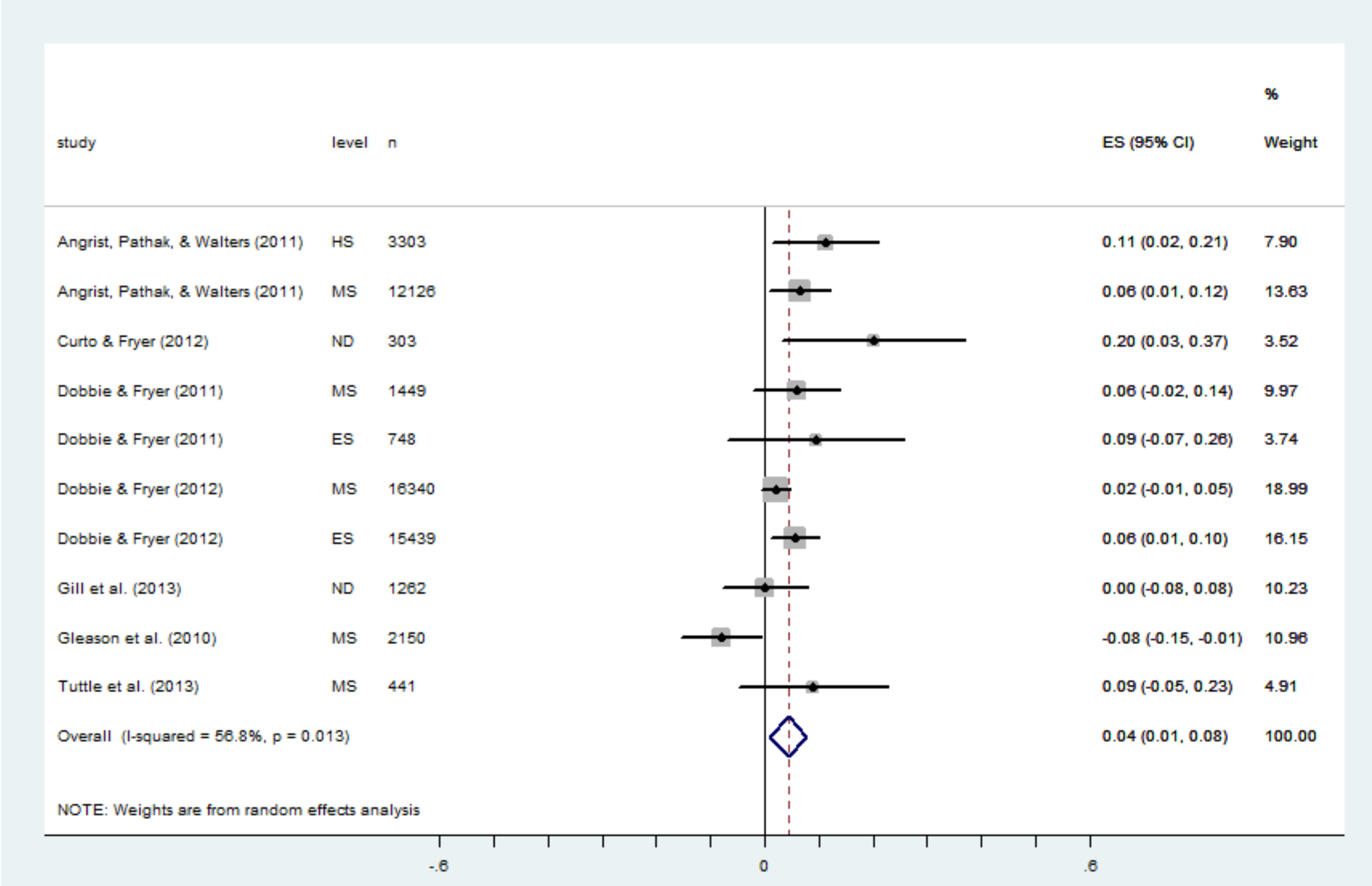

Notes: ES denotes elementary school; MS denotes middle school; HS denotes high school; ND indicates that study combines across grades. 
Figure 3. TOT estimates of individual-study and overall effect sizes for the impact all charter schools on ELA achievement.

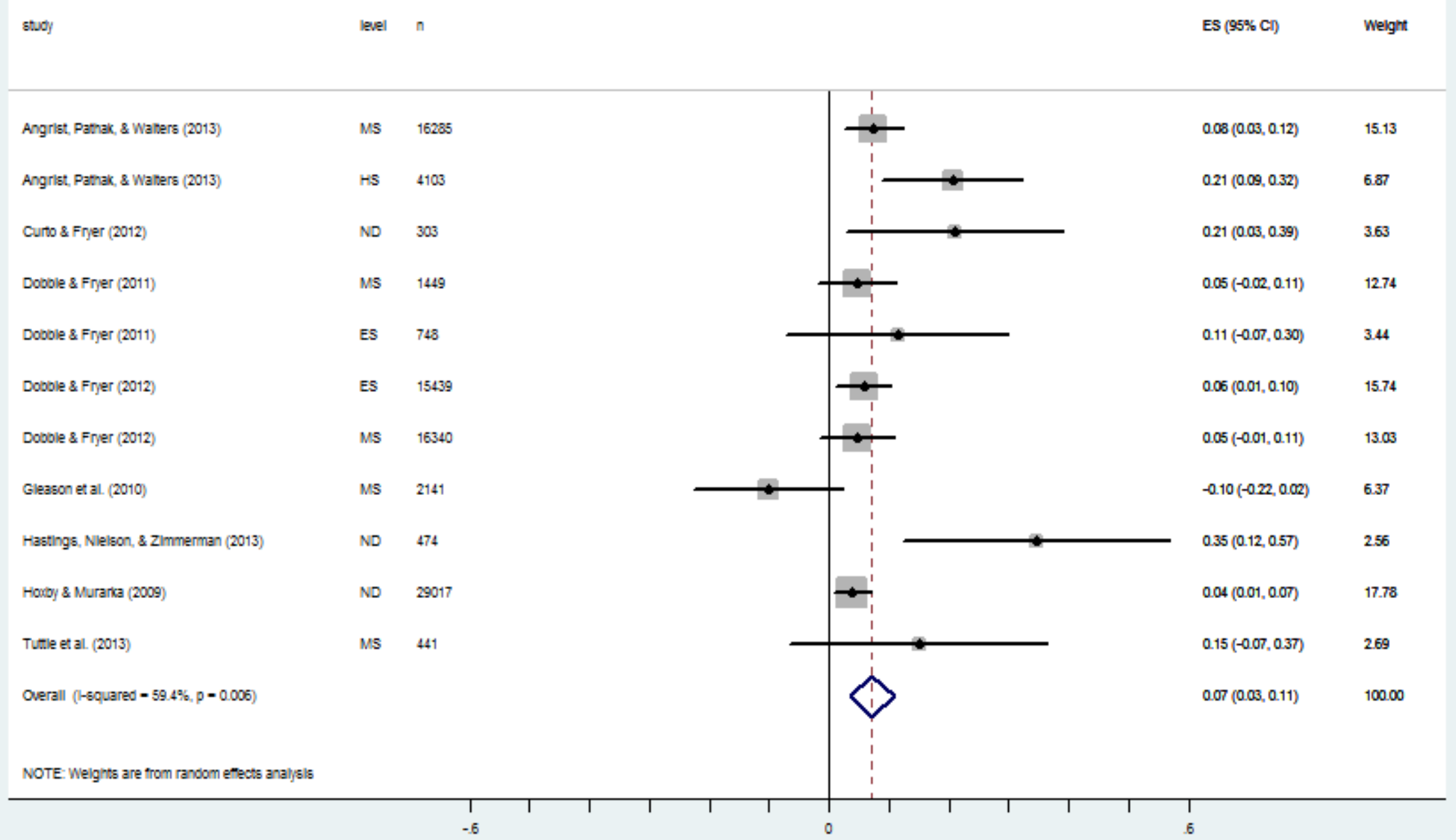

Notes: ES denotes elementary school; MS denotes middle school; HS denotes high school; ND indicates that study combines across grades. 
Figure 4. ITT estimates of individual-study and overall effect sizes for the impact all charter schools on math achievement.

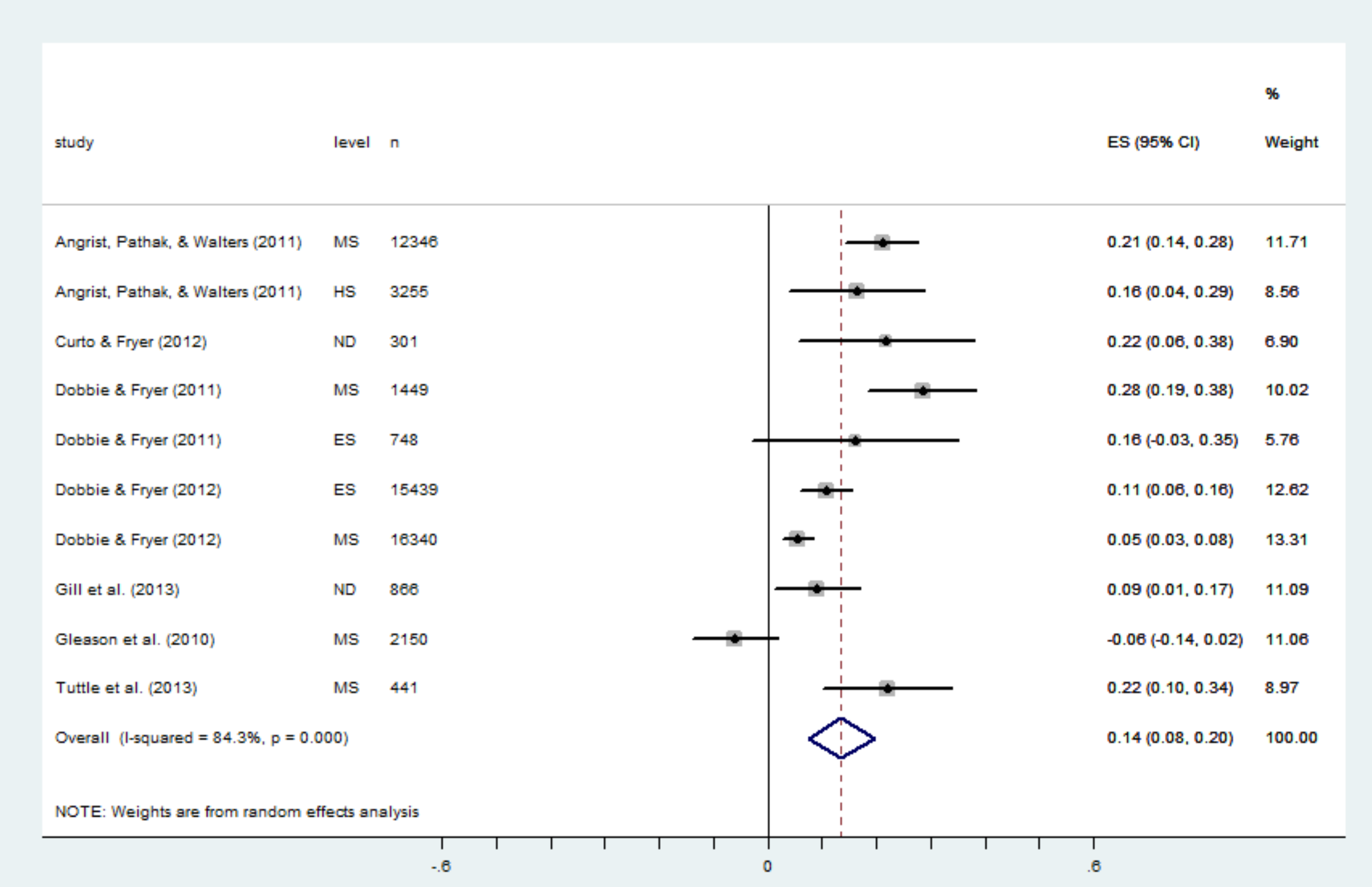

Note: ES denotes elementary school; MS denotes middle school; HS denotes high school; ND indicates that study combines across grades. 
Figure 5. TOT estimates of individual-study and overall effect sizes for the impact of all charter schools on math achievement.

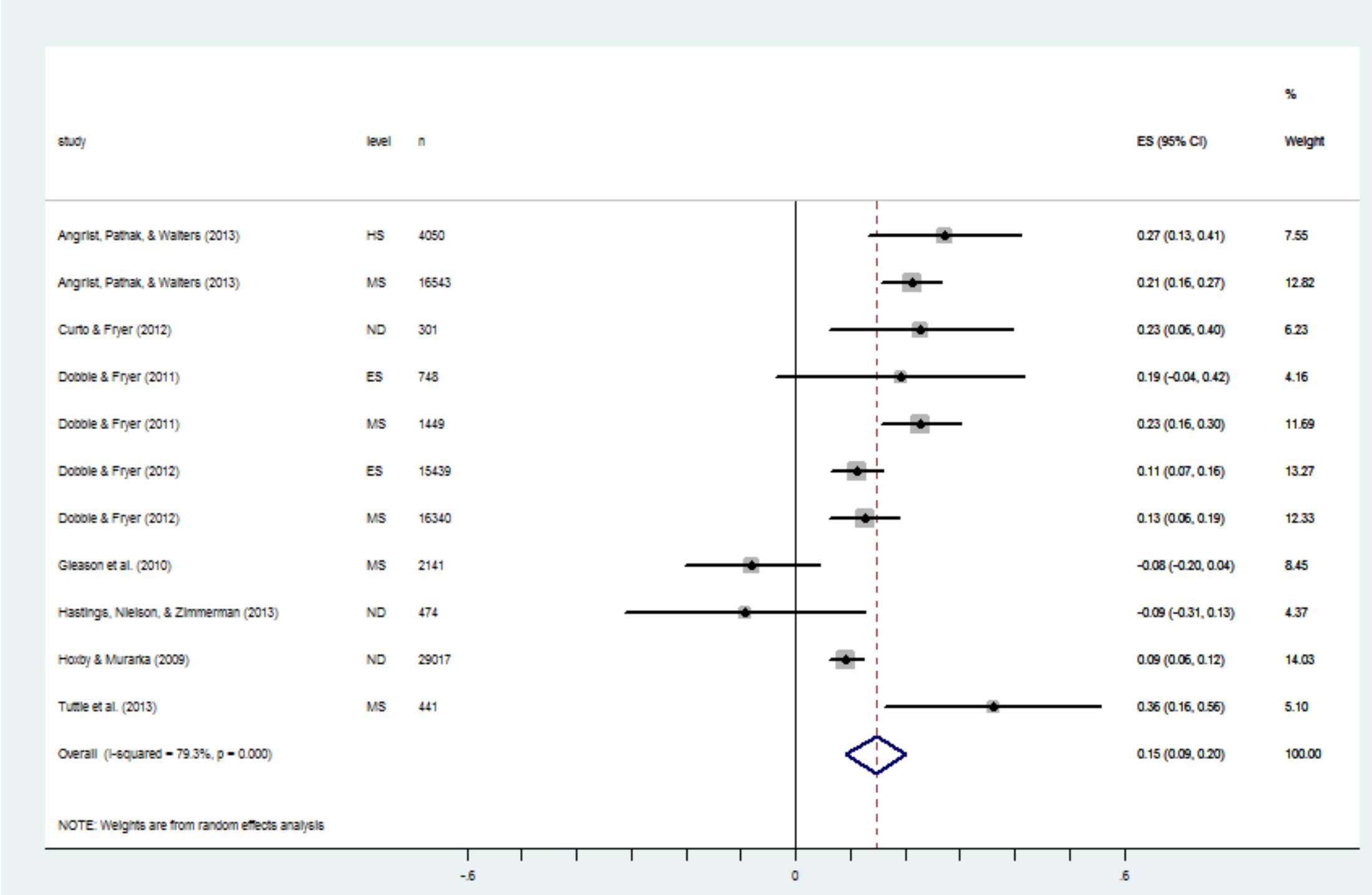

Notes: ES denotes elementary school; MS denotes middle school; HS denotes high school; ND indicates that study combines across grades. 
Figure 6. ITT estimates of individual-study and overall effect sizes for the impact of No Excuses charter schools on ELA achievement.

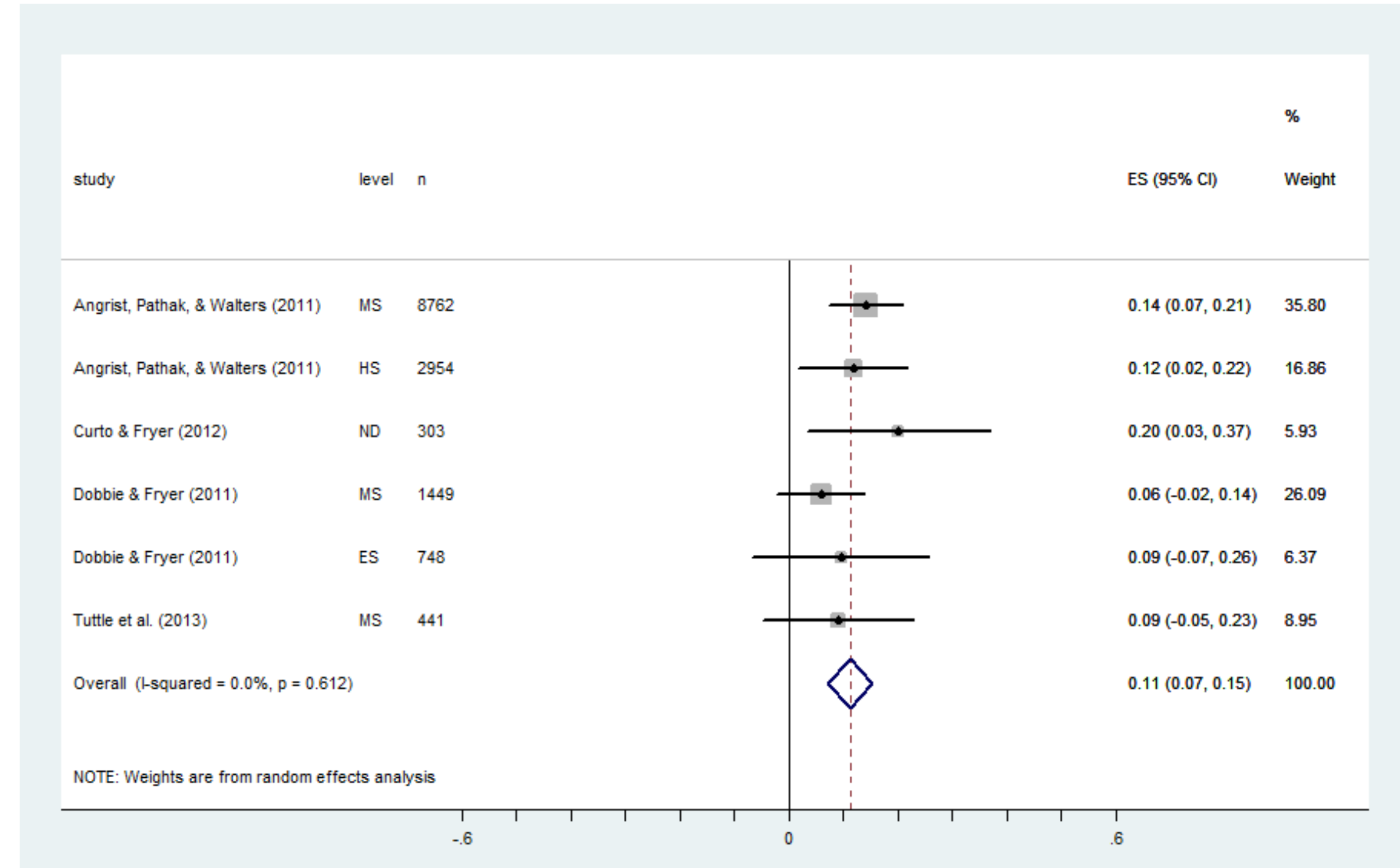

Notes: ES denotes elementary school; MS denotes middle school; HS denotes high school; ND indicates that study combines across grades. 
Figure 7. TOT estimates of individual-study and overall effect sizes for the impact of No Excuses charter schools on ELA achievement.

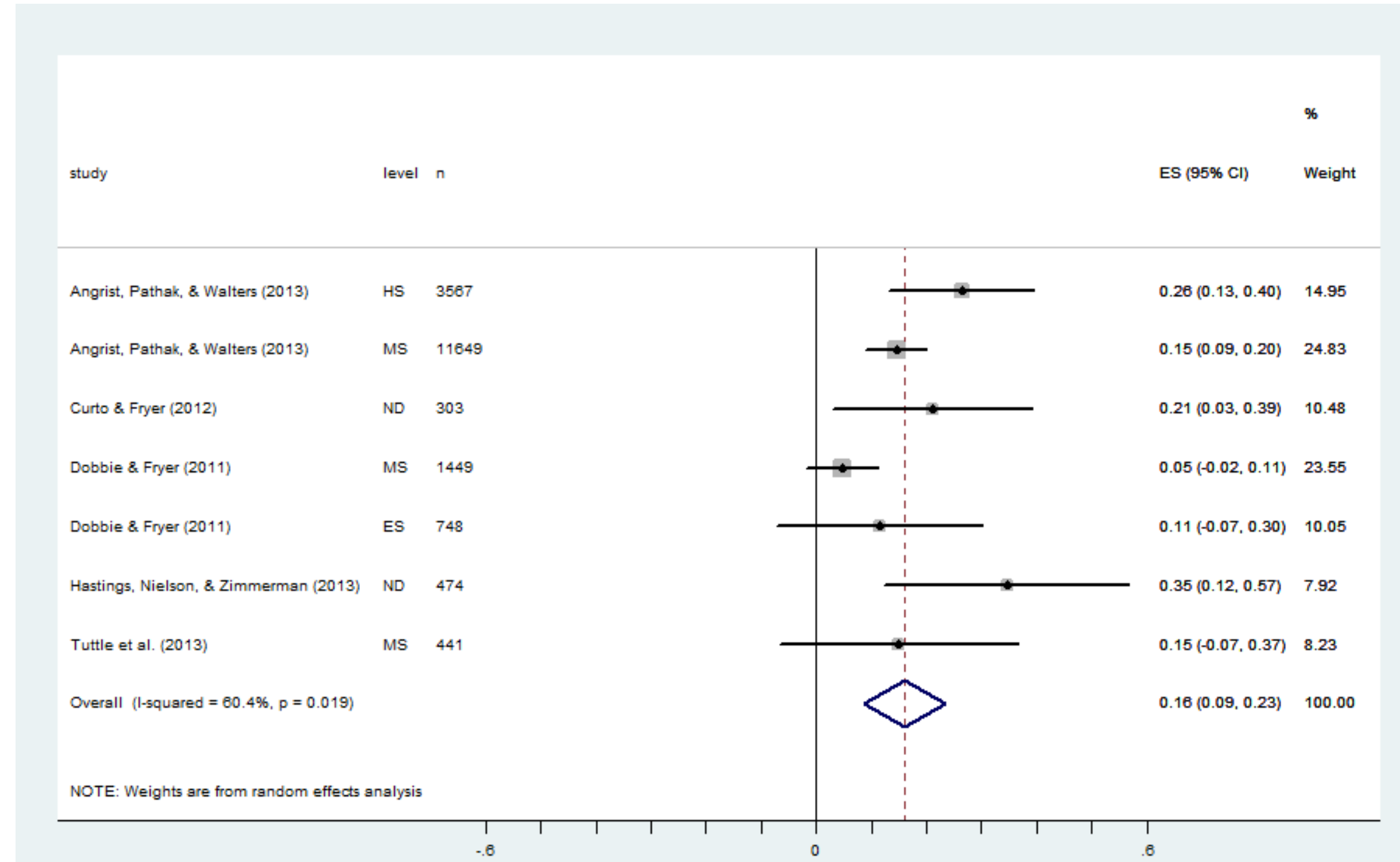

Note: ES denotes elementary school; MS denotes middle school; HS denotes high school; ND indicates that study combines across grades. 
Figure 8. ITT estimates of individual-study and overall effect sizes for the impact of No Excuses charter schools on math achievement.

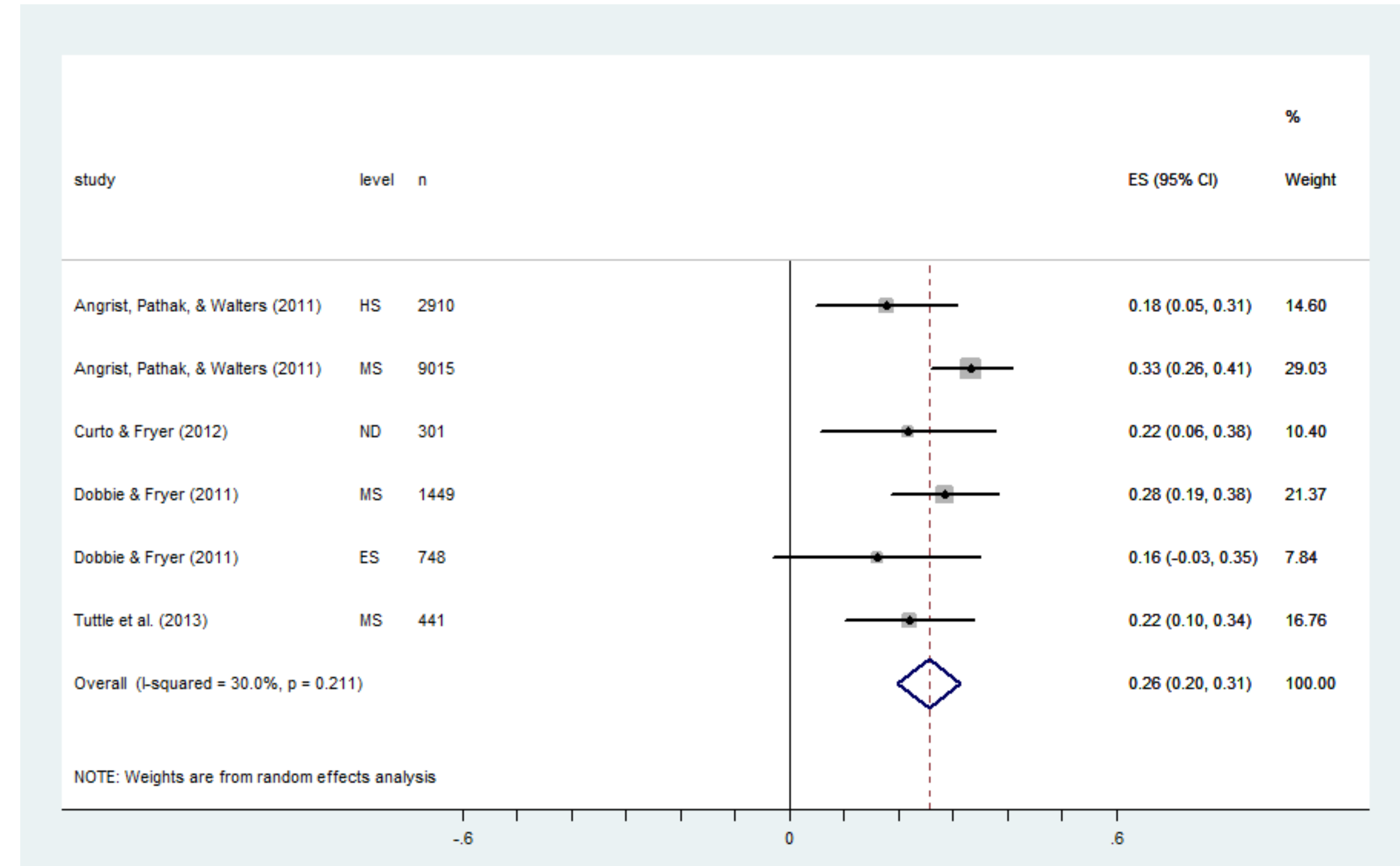

Notes: ES denotes elementary school; MS denotes middle school; HS denotes high school; ND indicates that study combines across grades. 
Figure 9. TOT estimates of individual-study and overall effect sizes for the impact of No Excuses charter schools on math achievement.

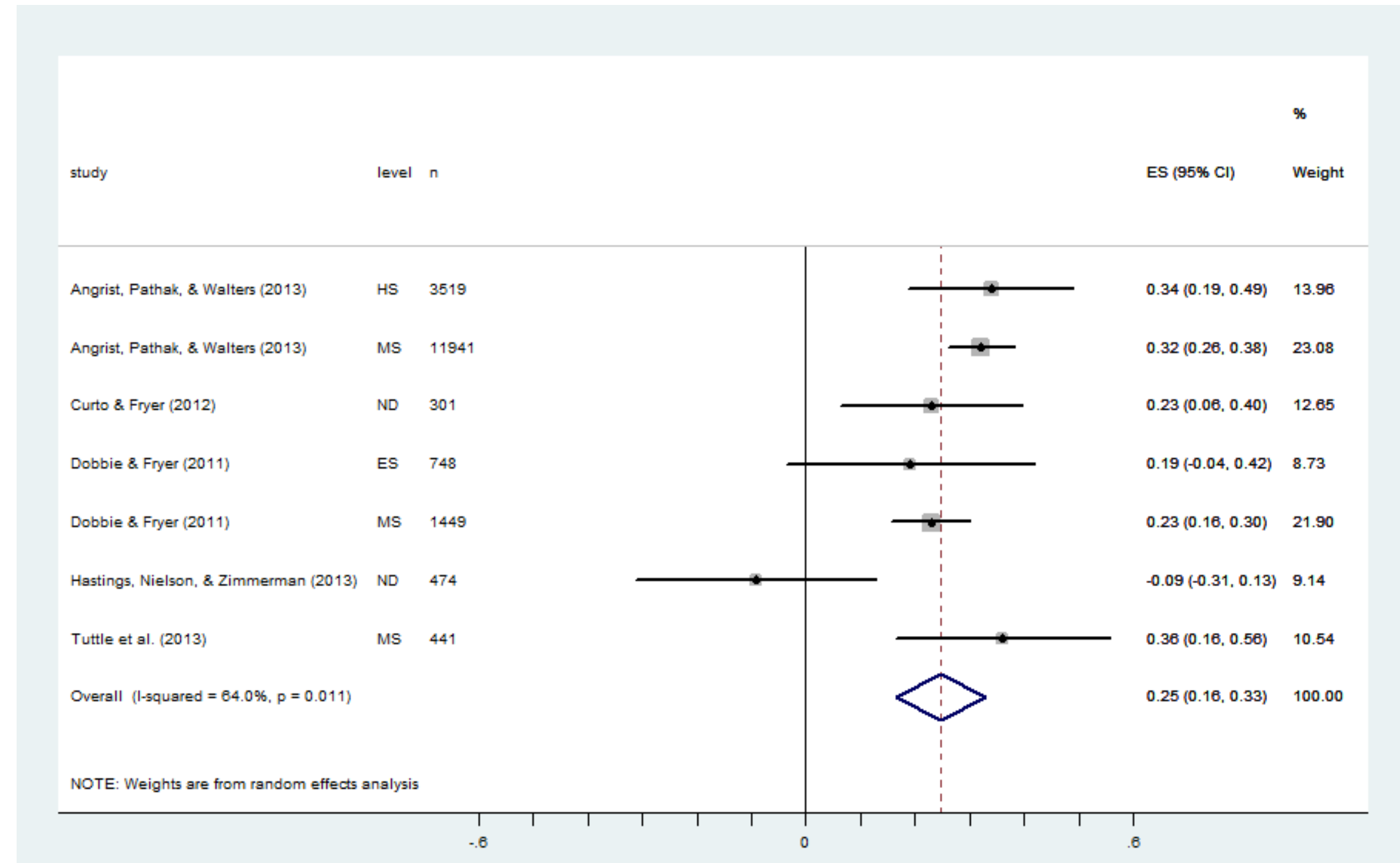

Notes: ES denotes elementary school; MS denotes middle school; HS denotes high school; ND indicates that study combines across grades. 